\title{
Effect of New Technology on Firms Business Objectives: A Case Study of Pak-Suzuki Company
}

\author{
Kashan Pirzada ${ }^{1}$ \& Monir Ahmed ${ }^{1}$ \\ ${ }^{1}$ School of Business Administration, Sindh Madressatul Islam University, Karachi, Pakistan \\ Correspondence: Kashan Pirzada, School of Business Administration, Sindh Madressatul Islam University, Karachi, \\ Aiwan-e- Tijarat, Road, 74000, Pakistan. Tel: 92-21-9921-7501-3. E-mail: kashan_pirzada@yahoo.com
}

Received: April 21, 2013

Accepted: May 9, $2013 \quad$ Online Published: May 12, 2013

doi:10.5430/ijba.v4n3p95

URL: http://dx.doi.org/10.5430/ijba.v4n3p95

\begin{abstract}
Importance of advancement of new technology in automobile industry with particular focus on Pakistan Suzuki Company's current implementation has been identified. The study is descriptive in nature, as sampling technique in the study is convenient as the company has not provided the sampling framework. Perception of advance technology survey has been conducted on 100 employees of Pakistan Suzuki motor company on the basis of four variables such as designing, manufacturing, planning and research, and engineering. The findings highlight that all the variables have strong correlations with new technology and firm business objectives. Moreover, inferential analysis indicates that majority of employees believe that the performance of the company has tremendously increased with the use of new technology. It is suggested that employees' perception towards impact of technology on business objectives should be conducted at a wider level. The effect of other factors on firm business objectives has been discussed and conclusion has been drawn accordingly.
\end{abstract}

Keywords: advance technology, automobile industry, business objectives, effects

\section{Introduction}

\subsection{The Problem}

Finding out factors organizations use to line up technology with their corporate ideas.

\subsection{Importance of the Problem}

Every organization uses the common technologies which in some way help the organization achieve its objectives easily. (Brenham and Trajtenberg, 1995). General purpose technology is best described as information technology rather than traditional capital investment. According to Surendra Gera \& Wulong Gu (September, 2004) Investment in new technologies, human capital, intangible activities and diffusion of knowledge are the main factors in organization which contribute to the growth of organization. They say Human Resource Management produces skilled and motivated employees who can deliver, who can change the organization's market and along with that they can acquire new technologies. According to Ivor Jonathan Farrell (May 2003) Study that alignment of information technology with corporate objectives will provide better benefit to the organization. So information technology is essential part of organization which provides better benefit to achieve organization objectives.

Organizations have intense competition among them due to the demand of consumers. To fulfill the demands of consumers, organization need to be innovate with respect product. Innovation mainly comes from new technology. Now every organization is dependent on new technology because they know it will improve their organization and it will lead to fulfillment of their objectives. To stay in business, organizations have to make use of new and innovative technologies.

According to Gray (1986), the strategic planning is handled poorly in most organization. In the mid 1980s this research was carried out. Gray found out that old business planning was still prevalent in organizations. The problems he cited were in connection with poor performance of managers and staff and formulation of the goals and lacking of linkage between strategic plans and other control system. These drawbacks can never lead to achieving any objective. To achieve the objectives all employees should have good relations and strong linkage with tactical strategy and control structure. 
Gray's study says, if tactical strategy is adopted in organization in good manner it would be carried out in stages. It would be maintained for a long time. It would progress slowly and decline in financial planning. Glaister \& Falshaw (1999) study that spread sheet techniques are used in strategic planning. In addition to that it develops with analysis and then it is to be forwarded while the organization implements planning and performs other activities.

Chan, Huff \& Copeland (1998) had also similar comments like some organizations don't have formalized strategies but all organizations have their strategies. Most of them just talk about it and most of them write their strategy and others don't even mention the word (p273). They also stated, the importance of strategic planning is that companies should execute their strategies as soon as possible because it's important for company to achieve their objective.

According to Pant \& Hsu, (1999); Reich \& Benbasat, (1996) to align information technology with corporate objectives the objectives should be clear and it should be brief and concise. It should cover all the aspects of the organization otherwise it would be difficult to align information technology with them. The business objectives should be clear that technology could be aligned with the business objectives and organization could easily achieve their objectives. Information technology highly supports the successful execution and implementation of those business objectives. Maryam Mousavi, Faieza Abdul Aziz and Napsiah Ismail (23 ${ }^{\text {rd }}$ December 2011) did research in which they adopted planning and research section in which they tried to found out that the existing advance technology is sufficient or not in planning and research section in which they found out that new technology is necessary to be adopted by organization.

\subsection{Objectives}

To explain factors firms use to line up their IT with their company aiming at introducing a fresh knowhow that has the ingredients in helping an organization enhancing its selling targets.

Sub-objectives of the study:

- IT professionals should be aware that they have to be more focused and to connect IT with the business

- The IT plans should have connections with strategic plans

- IT is linked with the organization's core competencies and fundamental strategies

\subsection{Merits of Technology}

With the technological machine people are getting help in every sector. It has made our life easier. Because of advance technology, people are making fewer mistakes. It is also saving our time. It has brought the world closer together; we share information quickly and efficiently from phones, internet, fax machines etc In automobile advance technology is essential part without it they can't achieve their objectives. Advance technology is the backbone of automobile company. Due to advance technology they bring innovation in cars and increase efficiency. Like virtual reality technology brings change in technology. Through this technology customer can easily understand the car which they want to buy. And it becomes easier for automobile company to know the taste of customer. Brynjolfsson and Hitt (1997) explored the ties of productivity growth with computers.

\subsection{Demerits of Technology}

The important disadvantage of technology is that the companies which adopt machines for improving their accuracy in fact brings in painful result for the workers. The workers lose their jobs. The disadvantage of advance technology is that machines are complex and complicated. To achieve anything one should have awareness and knowledge of that technology. Every organization is keen to adopt advance technology but there is lack of awareness in some companies. Due to that they don't operate the machines properly. Further maintenance problem arises.

After the World War I prosperity came in United State due to new technology. During 1920s new technology played very important role in bringing the cultural and great economic prosperity. This new technology didn't bring in negative effects, rather, it brought in new discoveries, new inventions, new advancements which improved the living standard in America. The first major invention was the automobile.. Henry Ford was the first inventor who developed a combustion engine in 1896. Cost wise it was affordable. It was popularly known as the Model-T. This replica got so much success that over 15 million were sold. In America automobile was increased and everyone was having car. In automobile business the Pak Suzuki is the first automobile industry which provides the most modern and manufacturing facilities in Pakistan. They have 150,000 vehicles capacity in annual production. It imports two products and produces six products. The vehicles they produce are cars, pickups, small vans, motorcycle and cargo. It holds 50\% market share. Pak Suzuki has a great role in developing Pakistan economy and industry. Pak Suzuki also participates in society development by creating opportunities for jobs and trying to improve the living standard of people. It is done through joint endeavors of sellers, traders and the company staff. 
Suzuki partnership with local Indian company Maruti which places them in India's largest automobile vendors, Pak Suzuki is doing export to Bangladesh items likeSuzuki Ravi, Liana, pickup and components. Due to the demand of consumers and similarity in vehicle the Pak Suzuki have a high competition with other automobile companies. Pak Suzuki was the first company which introduced CNG some 10 years ago. And this company was first which introduced seat belts. In 2011 they introduced new Swift 1300cc with Euro 3 technology, VV tech engine, ABS system that is automatic break system and electronic staring which gave them high profit in billions. Cultus and Mehran are also their famous products which gave them high profit. They are based on Euro 2 compliance. The crisis they faced is with Baleno in which they faced studs problem. They trained their employees so that they get awareness of their new technology which they use in their new products. Their business communication is done through online services. Now they are thinking to introduce and implement 2D bar code technology. With this they can work more efficiently and can easily achieve the objectives of organization. Pak Suzuki believes on kaizen. To meet limited capacity challenges at its existing plants, Maruti Suzuki has adopted kaizen methodologies in its production processes that would help it to rationalize its assembly lines. Kaizen is Japanese word which means 'improvement' or 'change for better'

\subsection{Relevant Scholarship}

The importance of information technology in the organization and aligning information technology with organization objectives helps organization to extend competitive advantage. According to Boar (1994) information technology is important to build in business because it creates competitive advantage and it is essential in worldwide competition (p16). The investment in information technology is positive for organization. It grows organizational performance. According to Brynjolfsson \& Hitt (1998), information technology investment is necessary in an organization. It provides positive impact. Some organizations have spent investment on information technology with little benefit whereas others have spent same amount with good success (p50). Investment information technology can give good growth to organization and along with that it will increase competitive advantage because now-a-days every organization is using advance technologies.

Hitt (1997) explored productivity growth's ties with computers. The result is positive. In other words, computers make positive contributions. Computers are an important part of technology which can change the productivity ratio. They play vital role in competitive advantage.

Baldwin and Sabourin (2003) link their study with the sector of food processing. They found that the plants which were using advance technology increased the labor productivity and market share during 1988 to 1997. More important in this study is that new technology is aligned with the business which adopts advance technology and which is linked with improving product quality and product development. Advance technology is the best practice in a firm. Due to advanced technology the competitive advantage of organization increases. Further they study that an organization's performance is just not only related to technology, but also to other areas of competencies. Advanced technologies and human resource strategies are equally important to increase productivity of organization. In human recourses strategic training experiences increase productivity gains. Organizations which want to improve quality give their employees necessary training and their employees learn how to use advanced technology. Along with use of advanced technology the employees' skills thrive and the organization draws benefit of it.

\subsection{Virtual Reality Technology}

Virtual reality technology is created with software and it presents an artificial environment and it is presented in such a way to users that the users accept that it as a real environment. In the computer it is experienced through two of the five sense sight and sound 3D image is the simplest form of virtual reality._According to Maryam Mousavi, Faieza Abdul Aziz and Napsiah Ismail (23rd august 2011) the three dimensional modeling (3D) and virtual reality technologies are used in industries in many respects. The virtual reality technologies are used as the initial group in the automotive industry. The automotive industries have to adopt advanced technology because without it they can't compete with its global competition. Virtual reality technology is important aspect using its effect on production process and designing procedure in industry. On adoption of virtual reality technology in industry are argued in the literature, for instance, (Zimmermann et al. (2008) have stated that it helps to take part in the procedure of decision-making and it will be provided by virtual prototype of new vehicles before making physical vehicles. It is capable of communicating between virtual models and engineers which provide demonstration analysis and presentation through three-Dimensional (3D) systems. Faieza and Mousavi (2009) have mentioned that virtual reality technology use in manufacturing applications as a process of planning to avoid mistakes in the planning and building processes. According to (Mousavi et al., 2009), the modern vehicles are growing complexity within the product development, supply chain, manufacturing and logistics processes that are important part of the modern automobile 
company. In this regard Vogt et al. (2005) says, virtual prototypes are used on ergonomic interior design of vehicle and the virtual manikins in the automotive domain and in the interior.

In Guo and Zhou (2007) research it is discussed that virtual test technology solves some problems related to large-scaled machinaries and machine parts. It can easily detect failures and faults and many other problems.

\subsection{Varaiables}

Maryam Mousavi (23 dec 2011) research proves that advance technology supports manufacturing, designing and engineering section. In this particular research it is proved that manufacture section is appropriate for virtual reality technology implementation in Malaysia. Another study demonstrated that the design section is strongly in the need of adopting virtual reality technology. According to Ivor Jonathan Farrell (2003) IT is an important part of organization. It supports every department in organization. It helps in achieving the objectives of organization. On IT alignment in organizations the concept was explained by Chan \& Huff (1993). Baldwin, Diverty and Sabourin (1995), connect technology surveys to longitudinal statistics on the presentation of mechanized plants. They study that those organizations which are using advanced technologies have an effect on the productivity growth. It is reflected in market share gains. The new technology and communication technology gives positive and best performance. But they said, information communication technology not only improves the productivity, but also helps other advanced technology to increase the productivity. They do better vis-à-vis those who utilize two secluded technologies. More important in this research paper is that the use of advance technology is associated with those business which adopt for practices. The investment in IT is positive for organization and it enhances organizational performance. According to Brynjolfsson \& Hitt (1998), the information technology investment gives benefit to an organization. It leads an organization to success. An organization which takes part in information technology investment does fairly well.(p50). Surendra Gera \& Wulong Gu (September, 2004) study shows that the Information \& communication technology improves the firm performance. Along with that they find the combination of high level to lower level brings in change. They said that the organization that combines organizational changes with Information \& communication technology gets good result. They find high level of productivity and their innovation comes to high rates. Their findings seem to be successful that organization should adopt Information \& communication technology as a system. According to Bresnahan and Trajtenberg (1995) general purpose technology is best described as information technology than the traditional capital investment. On the other hand, according to Brynjolfsson and Hitt (2000, p. 24) technologies bring benefit in economy because they facilitate in complementary innovations. Baldwin and Sabourin (2002) argue that just purchasing advanced technologies is not necessary. It does not guaranty success. It depends on how a firm implements these technologies. To implement advance technologies successfully human resource should be developed. The firm should overcome the financing problem associated with acquiring new technologies. And it requires best engineering and good working skills which will help in implement these advanced technologies.

\subsection{Theoretical Framework}

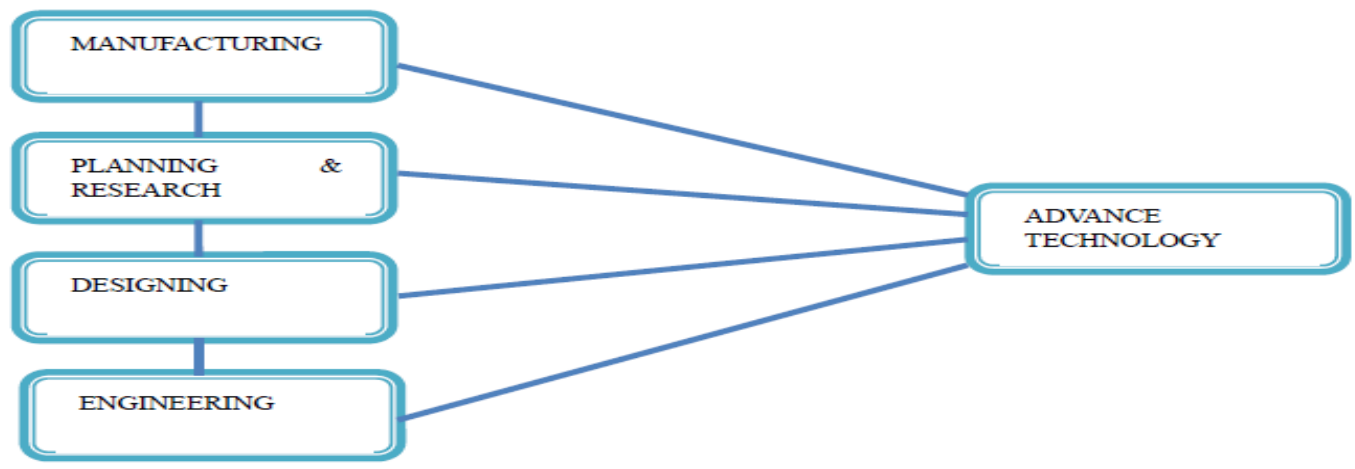

\section{Method}

The research is basically descriptive in nature because the same kind of research also been conducted in various countries. It was replicated in our country. It was estimated that employees of different department of Pak Suzuki Motor Company are around 3000, and as the company is not ready to provide the sampling framework the study has to rely on the convenient sampling method for collecting the facts. Sampling size was 100 employees of different departments of Pak Suzuki motor company. Questionnaire was used to gather data of the company. It consists of 20 items which stand on 5 points. They are: a) agree, b) powerfully agree, c) no option, d) disagree, and e) strongly 
disagree. The trustworthiness of the instrument was checked through Cronbach's alpha, mentioned below, the results shows that instrument was highly reliable and above the standard 0.6 highlighted in different studies. And data was tested by applying descriptive analysis, correlation, reliability test and T-test and SPSS were used for data analysis.

Table 1. Case processing summary

\begin{tabular}{lll}
\hline & $\mathrm{N}$ & $\%$ \\
\hline Cases & 100 & 40.0 \\
valid & & \\
Excluded(a) & 150 & 60 \\
Total & 250 & 100.0 \\
\hline
\end{tabular}

a. List wise deletion based on all variables in the procedure.

Reliability analysis

\begin{tabular}{ll}
\hline Cronbach's alpha & No of Items \\
\hline .806 & 4 \\
\hline
\end{tabular}

\subsection{Secondary Source}

Additionally data is also gathered from different published research papers from reputed journals were around nineteen.

\section{Results}

This part of analysis appears at descriptive variables measured in the research. The analysis of the data is conducted through correlation \& descriptive statistics.

3.1 Overall Descriptive Analysis

\begin{tabular}{lrrrrr}
\hline VARIABLE & N & \multicolumn{1}{c}{ Minimum } & Maximum & Mean & Std. Deviation \\
\hline Manufacturing & 100 & 1 & 4 & 2.03 & .462 \\
Designing & 100 & 1 & 4 & 2.11 & .554 \\
Planning \& Research & 100 & 1 & 4 & 2.16 & .531 \\
Engineering & 100 & 1.0 & 3.4 & 1.976 & .5267 \\
Valid N (listwise) & 100 & & & & \\
\hline
\end{tabular}

The data was gathered from 100 employees of Pakistan Suzuki.

(Scale: $1=$ strongly agree, $2=$ agree, 3 no opinion, $4=$ disagree, $5=$ strongly disagree)

\section{Discussion}

The above table 2 shows the descriptive analysis of 100 employee's responses for different variables. The scores variable values range from 1 to 5 based on the scale. The factors also ranked on the basis of mean (lowest mean is ranked $1 \&$ highest mean ranked 8). The mean score of the respondent for the manufacturing variable as 2.03 it means that the respondents agree that manufacturing is preferable factor for advance technology. The mean score of the respondent for the designing variable as 2.11 it means that the respondents strongly agree that designing is preferable factor for advance technology. The mean score of the respondent for the planning \& research variable as 2.16 it means that the respondents strongly agree that planning \& research is preferable factor for advance technology. The mean score of the respondent for the engineering variable as 1.976 it means that the respondents neutral.

\subsection{Correlations}

\begin{tabular}{lllll}
\hline Variables & Manufacturing & Designing & Planning \& Research & Engineering \\
\hline Manufacturing & 1 & $.643^{* *}$ & $.430^{* *}$ & $.497^{* *}$ \\
Designing & $.643^{* *}$ & 1 & $.553^{* *}$ & $.460^{* *}$ \\
Planning \& Research & $.430^{* *}$ & $.553^{* *}$ & 1 & $.494^{* *}$ \\
Engineering & $.497^{* *}$ & $.460^{* *}$ & $.494^{* *}$ & 1 \\
\hline
\end{tabular}

** Correlation is significant at the 0.01 level (2-tailed). 


\section{Discussion}

The above table 3 of correlation test shows that all the variables strongly positive correlated in the selection of preferred advance technology. Mainly the convenient \& efficiency contribute more in identifying the perception of employees in the organization. Manufacturing, designing, planning \& research \& engineering are directly contributing in selecting preferred advance technology.

3.3 One-Sample T- Statistics

\begin{tabular}{lllll}
\hline VARIABLES & $\mathbf{N}$ & Mean & Std. Deviation & $\begin{array}{l}\text { Std. } \\
\text { Mean }\end{array}$ \\
\hline Manufacturing & 100 & 2.03 & .462 & .046 \\
Designing & 100 & 2.11 & .554 & .055 \\
Planning \& Research & 100 & 2.16 & .531 & .053 \\
Engineering & 100 & 1.976 & .5267 & .0527 \\
\hline
\end{tabular}

Test Value $=2$

\begin{tabular}{|c|c|c|c|c|c|c|c|}
\hline & \multirow{2}{*}{$\begin{array}{l}\mathrm{t} \\
\text { Lower }\end{array}$} & \multirow{2}{*}{$\begin{array}{l}\text { Df. } \\
\text { Upper }\end{array}$} & \multirow{2}{*}{$\begin{array}{l}\text { Sig. (2-tailed) } \\
\text { Lower }\end{array}$} & $\begin{array}{l}\text { Mean } \\
\text { Difference }\end{array}$ & \multicolumn{2}{|c|}{$\begin{array}{l}95 \% \text { Confidence Interval } \\
\text { of the Difference }\end{array}$} \\
\hline & & & & & Upper & Lower & Upper \\
\hline Manufacturing & & .562 & 99 & .575 & .026 & -.07 & .12 \\
\hline Designing & & 2.020 & 99 & .046 & .112 & .00 & .22 \\
\hline $\begin{array}{l}\text { Planning } \\
\text { Research }\end{array}$ & $\&$ & 3.052 & 99 & .003 & .162 & .06 & .27 \\
\hline Engineering & & -.456 & 99 & .650 & -.0240 & -.129 & .081 \\
\hline
\end{tabular}

\section{Discussion}

The test is carried out via T-test one sample variable analysis. The entire variables are statistically important except Engineering at $5 \%$ level of significance. So, the study ends with a note that variables are highly favorable for advance technology.

\section{Conclusion}

This study is conducted through survey of 100 employees of Pak Suzuki Motor Company. Advance technology is main variable of this study which was depend on manufacturing, designing, engineering and planning and research sections. Study is about the Importance of the new technology that how much is it important to achieve organization objectives. Advance technology brings innovation which play as back bone of organization. In automobile industry Kaizen is very important because change is better for automobile industry. Automobile industry depends on advance technology. In advance technology there are merits and demerits also. Planning and research is important section play important role to acquire advance technology .just to acquire advance technology is not only important but most important thing is to implement advance technology in successful way.

Advance technology is a competitive advantage for automobile industry in advance technology information technology plays important role. Along with that virtual reality technology in automobile industry is most important. It helps an automobile industry in manufacturing and designing. Advance technology highly supports manufacturing, designing and engineering section. The result of this study validates that all the variable means indicate that advance technology plays an important role in automobile industry. Majority of employees prefer that advance technology can help an automobile industry to achieve its objectives particularly Pakistan Suzuki. Mainly engineering and manufacturing variables contribute more in highlighting the effect of advance technology.

\section{Acknowledgements}

Firstly, I am thankful to my co-author Monir Ahmed for his contribution in this study. Secondly, Iam grateful to the employees of Pakistan Suzuki motor company who helped me in data collection process. 


\section{References}

Boar, H., \& Brenard, T. (1994). Logic and information technology strategy separating sense from nonsense. Journal of system, Amsterdam, 167-181.

Brynjolfsson, E. (1997). Information technology and organization design. MIT sloan school working paper.

Brynjolfsson, E. (2000). Beyond Computation: Information Technology, Organization Transformation and Business Performance. Journal of Economic Perspectives, 14, 23-48. http://dx.doi.org/10.1257/jep.14.4.23

Chan, E., Yolande, C., \& Sid, L. (1993). Strategic Information Systems Alignment. Business Quarterly, 58(1), 51-55.

Chan, E., Yolande, C., Sid, L., \& Copeland, G. (1998). Assessing Realized Information Systems Strategy. Journal of Strategic Information Systems, 6(4), 273-298. http://dx.doi.org/10.1016/S0963-8687(97)00005-X

David, S., \& Baldnin, J. R. (2003). "Impact of advanced technology" use of firm performance in the Canadian food processing sector, economics analysis research paper. Analytical studies branch, Ottawa statistics Canada.

Diana, D. (1991). 'Electronic' study book platform. Journal of Education \& Training Technology International, 28(4), 347-354. http://dx.doi.org/10.1080/0954730910280411

Erick, B., \& Hitt, M. (1998). Beyond the productivity paradox. Communication of the ACM, 41(8), 49-55. http://dx.doi.org/10.1145/280324.280332

Farrell, B., \& Trajtenberg, F. (1995). General Purpose Technologies, 'Engine of Growth'? Journal of Econometrics, 65, 83-108. http://dx.doi.org/10.1016/0304-4076(94)01598-T

Gera, S. (2004). The effect of organizational innovative and information technology on firm performances. International Productivity Monitor, (9), Canada.

Glaister, K., \& Falshaw, R. (1999). Strategic Planning: Still Going Strong? Long Range Planning, 32(1), 107-116. $\mathrm{http}: / / \mathrm{dx}$. doi.org/10.1016/S0024-6301(98)00131-9

Glaister, K., \& Falshaw, R. (2000). Strategic Planning: Still Going Strong? Long Range Planning, 34(1), 97-109.

Gray, H. (1986). Uses and Misuses of Strategic Planning. Harvard Business Review, 64(1), 89-97.

Horner, R., \& Izak, B. (1996). Measuring the Linkage between Business and Information Technology Objectives. MIS Quarterly, 20(1), 55-81. http://dx.doi.org/10.2307/249542

James, C., Bracheau, D., \& Brian, J. (1996). Key issue in information system management. 1997-95 Sim Delphi Result MIS.

Jonathan, F. (2003). Aligning IT to corporate objectives organizational factors in use. Macquarie Graduate School of Management, Macquarie University, Sydney.

Mousavi, M. (2011, December 3). Virtual reality adaption capability Malaysian automotive manufacturing industry. Department of Mechanical and Manufacturing Engineering, University Putra Malaysia, 43400 Serdang, Selangor, Malaysia.

Sabourin, D., \& Baldwin, R. (2002). Advanced Technology Use and Firm Performance in Canadian Manufacturing in the 1990s. Industrial and Corporate Change, 11(4), 761-89. http://dx.doi.org/10.1093/icc/11.4.761

Schroder, R. M., \& Beautment, N. B. (1997). Technology, manufacturing performance and business performance amongst Australian manufacturers. Technovation, $17(6), \quad$ 297-307. http://dx.doi.org/10.1016/S0166-4972(97)00011-4 